УДК 343.22

004.8
O. E. Radutniy,

$\mathrm{PhD}$ in Law, Docent of Criminal Law

Department № 1 of the Yaroslav Mudryi

DOI: https://doi.org/10.21564/2311- National Law University (Kharkiv, 9640.2021.16.243743 Ukraine)

\title{
LEGAL VIEW AT A DIGITAL HUMAN BEING
}

In continuation of previous research, the article offers a legal view at certain features of the digital human being and the formulation de lege ferenda of the special characteristics of a person of the offense. One of the problems is the question about delusion or weakness of will for digital human being, the decision was made by artificial intelligence, which may call into question the fact that there is a factual basis for legal liability. Regarding the digital person, the possibility of escalation of improved intelligence in all spheres of economic, political, corporate, information and military confrontation is argued. It has been proven that artificial intelligence can eliminate the need to think by human and digital human being, and then eliminate the ability to do it.

Key words: artificial intelligence, person of the delict, person of the offense, bioengineering, cyborg, inorganic life form, Homo sapiens, Homo numeralis, Homo digitalis, Homo horologium, digital human being.

Setting a problem. According to Carl Linnaeus (Carl Linné, Carolus Linnaeus, Carl von Linné, 1707-1778), the word sapiens in the Homo sapiens was to emphasize the presence of intelligence only in human being. This unique property was to distinguish human being among all other beings on the planet.

Today this thesis does not seem indisputable not only in terms of The Cambridge Declaration on Consciousness (July 7, 2012) ${ }^{1}$, but also in connection with the emergence of Homo sapiens a new powerful evolutionary competitor, which was noted in previous publications ${ }^{2}$.

\footnotetext{
${ }^{1}$ The Cambridge Declaration on Consciousness of 7 July 2012. Written by Philip Low and edited by Jaak Panksepp, Diana Reiss, David Edelman, Bruno Van Swinderen, Philip Low and Christof Koch. University of Cambridge. URL: http://fcmconference.org/img/CambridgeDeclarationOnConsciousness.pdf (дата звернення: 21.07.2021).

${ }^{2}$ Radutniy O. E. Novel Criminal Delicts Related to Digital Human Being. Herald of the Association of Criminal Law of Ukraine. Vol 1, No 13 (2020). URL: http://vakp.nlu.edu.ua/issue/view/12594. doi: https://doi.org/10.21564/2311-9640.2020.13.204761 (дата звернення: 21.07.2021).
} 
Therefore, along with artificial intelligence, it is digital human being ${ }^{3}$ $\left(\right.$ Homo digital $^{4}$, Homo numeralis, Homo digitalis, Homo Horologium ${ }^{5}$ ).

The path that humanity has developed over the last 100 years of 200,000 years of human existence is called gene-culture coevolution or biocultural evolution (Kevin Laland), technological-physiological evolution (Robert Fogel), or metabiological evolution (Jonas Edward Salk).

We observe a significant change in life expectancy, key indicators of body (height, weight, strength), disease pathomorphosis, human IQ and so on. In addition, ruthless and unethical natural selection has been eliminated, they have already learned to interfere in the genetic code, clone organs, synthesize artificial bacteria etc. In particular, Israel has developed and activated a computer in the form of a tube in the human heart ${ }^{6}$. A scientific program to decipher the connection (complete description of the structure of connections in the nervous system) of the human brain is gaining momentum, it will transpose the individual into the "cloud", live there forever and get rid of somatic and psychological suffering.

Thus, the modern evolution of human being into digital human being is mostly artificial and occurs in several main directions, in particular:

1) bioengineering (interference in the human organism at the cellular and atomic levels; development of hybrid nanorobots based on synthetic proteins; implantation of reconstructed DNA; growing organs to order or 3D printing them; a successful attempt to remove from the human embryo a DNA defect responsible

\footnotetext{
${ }^{3}$ Радутний О.Е. Правові аспекти феномену цифрової людини в кібернетичному та іншому просторі. Забезпечення кібербезпеки: правові та технічні аспекти: збірник тез наукових доповідей науковопрактичного семінару (м. Харків, 8 листоп. 2018 р.). Харків: Нац. аерокосм. ун-т ім. М. Є. Жуковського «XAI», 2018. С. 57-63.

${ }^{4}$ Радутний О. Е. Розвиток кримінально-правової доктрини у напрямку визнання штучного інтелекту та цифрової людини суб'єктом правовідносин та суб'єктом злочину. Ефективність кримінального законодавства: доктринальні, законотворчі та правозастосовні проблеми ї̈ забезпечення: матер. міжнарод. наук.-практ. кругл. столу (м. Харків, 17 трав. 2019 р.). Харків: Константа, 2019. С. $202-213$.

5 Радутний О. Е. Кваліфікуючі ознаки, пов’язані з досягненнями наукового прогресу (біоінженерія, штучний інтелект, неорганічна та змішана форма життя). Актуальні проблеми кримінального права, кримінології та кримінально-виконавчого права: матер. Всеукр. наук.-практ. конф. (м. Дніпро, 25 трав. 2018 р.). Дніпро: Дніпроп. держ. ун-т внутр. справ, 2018. С. 41-43.

6 Computer inside the heart aims to aid treatment. BBC News, Technology, 2 March 2020. URL: https://www.bbc.com/news/av/technology-51660393/computer-inside-the-heart-aims-to-aid-treatment (дата звернення: 21.07.2021).
} 
for heart disease (potentially such a technology will be able to «purify» the genes of all humans from inherited diseases) etc.);

2) creation of a living being that combines organics with inorganics, or formation of a cybernetic organism (cyborg) - a biological organism that contains mechanical and / or electronic components (eg., cochlear implants to renew hearing and take it on a new level, iBrain Neurointerface for fine motor control tested by Stephen Hawking, technological prostheses as an i-LIMB Pulse artificial arm or a knee prosthesis RheoKnee capable to self-training with artificial intelligence, retinal prosthesis as a microchip by Retina Implant, artificial heart by Total Artificial Heart, EnChroma glasses for color perception, etc.);

3) creation of an inorganic life form (copying or complete transfer consciousness, intelligence and personality of the human being to digital or other container; scanning of the human brain and renewal of its electronic copy, the acquisition of digital immortality with the ability to transfer the identity of the human being to the «cloud» of the digital server or due to the spraying by blockchain technology).

The possibility of combining carbon technology (human being) with silicon technology (artificial intelligence, implants, objects of robotics) according to Michio $\mathrm{Kaku}^{7}$, or transfer the structure of the human brain one neuron by one to inorganic or semi-organic carrier, creates a new powerful challenge for legal doctrine.

An analysis of recent research and publications on this topic. Related question of the human being characteristics through the optics of law has been paid attention in nearly all scientific researches by M. I. Bazhanov, V. S. Batirgareeva, U. V. Baulin, V. I. Borisov, I. M. Danshin, L. N. Demidova, O. V. Zaitsev, A. A. Muzika, V. O. Navrotsky, N. I. Panov, V. V. Stashis, V. Y. Tatziy, V. O. Tulyakov, P. L. Fris, V. I. Shakun, M. I. Khavroniuk, V. B. Kharchenko,

${ }^{7}$ Kaku M. (2008). Physics of the Impossible: A Scientific Exploration Into the World of Phasers, Force Fields, Teleportation, and Time Travel. Doubleday Publishing, Duke University Libraries. P. 233. 
V. V. Ustimenko and many others. Significant contributions to the study of the phenomenon of artificial intelligence have been made by James Barrat, Eric Horvitz, Niklas Boström, Elon Musk, George Dyson, Kevin Kelly, Ryan Calo, Peter M. Asaro, Vernor Steffen Vinge, O. A. Baranov, M. V. Karchevskiy, V. A. Misliviy, N. A. Savinova, E. O. Kharitonov, O. I. Kharitonova etc. However, the problem of digital human being is only at the beginning of the study.

T. S. Akhromeeva, G. G. Malinetskiy, S. A. Posashkov ${ }^{8}$ assume great risks arise when passing to the «fast world», approaching the «Lem's barrier» (under the name of Stanisław Lem - transition to control systems in such a fast time, in which an adequate response requires the exclusion of a human being from the decisionmaking circuit). It happens when artificial intelligence systems are assigned strategically important tasks that they must solve at a speed inaccessible to humans. It is noteworthy that the digital human being can be equipped with such systems. There is the transition to control systems in such a fast time, in which an adequate response requires the exclusion of a human being from the decisionmaking circuit.

Tomáš Kopeček ${ }^{9}$ believes what can be taken as a lesson here is that potential empiric research should take in game all these effects. Otherwise, it may will describe some facets of the topic, but probably it will create distorted image. AI is not clear hard science. AI is human project as most others and is influenced by and influences living world also in purely social ways.

Alcibiades Malapi-Nelson ${ }^{10}$ affirms that Homo sapiens exists at all is, in Darwinian evolution, exclusively due to chance. There is no «special place» in nature for our species. We came, and since no species is eternal, we will also go.

${ }^{8}$ Ахромеева Т. С. Пределы и риски цифровой трансформации / Т. С. Ахромеева, Г. Г. Малинецкий, С. А. Посашков. Цифровая трансформащия. 2020. № 2 (11). С. 51-57. doi: https://doi.org/10.38086/2522-96132020-2-51-57 (дата звернення: 21.07.2021).

9 Kopeček, Tomáš. (2015). Anthropomorphization of Artificial Intelligence. Bachelor thesis. Masaryk University Department of Sociology. Brno 2015. 40 p.

${ }^{10}$ Malapi-Nelson, Alcibiades. (2018). Classical Cybernetics and Transhumanism: A Reply to Richmond's Review of The Nature of the Machine and the Collapse of Cybernetics. Sage Publishing, Philosophy of the Social Sciences, 2018, Vol. 49, issue 1, page(s): 64-68. doi: https://doi.org/10.1177/0048393118811308 (дата звернення: 21.07.2021). 
Transhumanism rejects this view both morally and metaphysically. Ethically, it is unapologetically «human supremacist» (e.g., its closest ecological position for the betterment of the environment, eco-modernism, is clearly anthropocentric). Metaphysically, it asserts that we can increasingly locate ourselves cognitively «outside» evolution (in virtue of not just being part of it, but also knowing that we are part of it) and steer it, so that the survival of our species, contra Darwin, is secured.

The purpose of the study is to formulate certain features of the digital human being and the definition de lege ferenda of the special characteristics of a person of the offense, to consider the problem about delusion of will for digital human being, which may call into question the fact that there is a factual basis for legal liability.

Presenting main material. According to N. N. Chursin ${ }^{11}$ mankind gradually becomes more dependent on the degree of attachment to external memory (text repositories), hardware and software for its processing, than on communication with similar beings. As a result, all information processes, including decisionmaking, leave the biological womb and move to the silicon world. Quoting Haig Matt $^{12}$, we are gradually immersed in a world in which we expect more from technology and less from each other.

But this is not the only problem, because we live in a more interesting time. Thus, researchers at Scripps ${ }^{13}$ were able to create the first semi-synthetic bacterium in history from two new nucleobases in addition to the existing basic ones (adenine (A), cytosine $(\mathrm{C})$, guanine $(\mathrm{G})$, thymine $(\mathrm{T})$, and uracil ), which make up the DNA of any biological organism, and life has received new building blocks.

\footnotetext{
11 Чурсин Н. Н. Понятие тезауруса в информационной картине мира: монография. Луганск: Изд-во «Ноулидж», 2010. С. 290.

12 Haig Matt. Notes on a nervous planet. Country Edinburgh, United Kingdom: Canongate Books, 2019. $320 \mathrm{pp}$.

${ }^{13}$ Zhang, Y., Ptacin, J., Fischer, E. et al. A semi-synthetic organism that stores and retrieves increased genetic information. Nature 551, 644-647 (2017). doi: https://doi.org/10.1038/nature24659 (дата звернення: 21.07.2021).
} 
Implants that improve certain physical properties of the human body (strength, agility, flexibility, endurance etc.) can eliminate heavy, dangerous or tedious physical labor, as well as expand horizons (better to hear, see, perceive all the signals of the world around).

Implants that improve individual human cognitive properties (memory, analytical skills, processing significant amounts of information, the ability to distinguish the main from the insignificant, mobility of the mind, the ability to argue and find relationships, come to conclusions through a chain of thought, critical thinking, breadth) are able to free the mind from routine work or just as significantly improve its results.

In particular, it means being able to process and archive huge amounts of information, including Big Data. Then, in some areas, humanity can claim the return of victory over inorganic artificial intelligence in the game of chess after 1997 (victory over the current champion Gary Kasparov, after which no one claimed to be superior) and in the ancient Chinese game of Go (Weiqi, Weichi) after 2016 (similar story to Lee Sedol), if a digital human being is able to handle a huge library of debuts, standard endings and millions of games that have already taken place, as well as compete in the development of non-standard solutions. And this is taking into account that the possible number of combinations on the board is $10^{53}$ variants for chess and $10^{123}$ variants for Go (Weiqi, Weichi), which is 40 orders of magnitude higher than the possible number of atoms in the Universe.

There are even more expectations regarding the interaction of the neural system of the human brain with neural networks of artificial intelligence. They are planned to be endowed with such properties as full knowledge of the principles of their construction and work, self-study, self-development, self-restructuring, selfimprovement (the first version forms an improved version of itself and so rewrites the program indefinitely), autonomy, independence and independent implementation. 
It is possible that the neural systems of the human brain and the neural networks of artificial intelligence will learn to complement and train each other in some way.

A huge problem can be the inability to recognize the algorithm of selflearning artificial intelligence during decision-making. Already today, in many cases, this is a black box with no feedback when we have a result but do not know what arguments or criteria were used. Developers of the algorithm can not fully report on what is happening in the «primordial soup» of artificial neural networks. Primordial soup, or prebiotic soup (also sometimes referred as prebiotic broth), is the hypothetical set of conditions present on the Earth around 4.0 to 3.7 billion years ago. It is a fundamental aspect to the heterotrophic theory of the origin of life, first proposed by Alexander Oparin ${ }^{14}$ in 1924, and John Burdon Sanderson Haldane ${ }^{15}$ in 1929.

In the nearest future, it will be difficult to determine whether a certain act of behaviour of a digital human being is his free will, or the decision was made for him by algorithms of artificial intelligence, which is built into a particular implant.

Meanwhile, the assertion of the relatively free will of the individual is the cornerstone of any legal liability, including civil, administrative, financial or criminal and so on. The weakness of the will of the individual may call into question the existence of a factual basis for legal liability. Similarly, cases of unconscious use of a digital human being to commit an offense or an act undesirable for him or her in connection with unlawful interference or control of his or her implant under the control of artificial intelligence are not excluded.

A digital human being may be able to consider more than 5-7 factors when making a decision, or interact effectively with more than 5-7 other people, or

${ }^{14}$ Oparin A. I. (1924). The Origin of Life (translation by Ann Synge of A.I. Oparin (1924) Proiskhozhdenie zhizny. Moscow. Izd. Moscovskiy Rabochiy). URL: https://breadtagsagas.com/wp-content/uploads/2015/12/AIOparin-The-Origin-of-Life.pdf (дата звернення: 21.07.2021).

${ }^{15}$ Haldane J. B. S. (1929). The Origin of Life. URL: https://www.uv.es/ orilife/textos/Haldane.pdf (Cite: Tirard S. J. B. S. Haldane and the origin of life. J Genet. 2017 Nov; 96(5):735-739. doi: https://doi.org/10.1007/s12041-017-0831-6. PMID: 29237880) (дата звернення: 21.07.2021). 
common interact with more than $120-150$ people (Dunbar`s number ${ }^{16}$ - a suggested cognitive limit to the number of people with whom one can maintain stable social relationships, relationships in which an individual knows who each person is and how each person relates to every other person). Communication, information processing and decision-making for the digital human being can enter a phase of «fast time», in which the brain processes of the average person may seem humiliatingly slow. These comparisons can provoke the superior attitude of the digital human being to all other humanity.

In addition, as predicted by Stanisław $\mathrm{Lem}^{17}$, unheard of fast machines can make unheard of quick mistakes. Today, examples of such errors can be found in algorithmic trading systems on stock exchanges ${ }^{18}$ and in many other areas. Therefore, the transition to a «fast world» can both increase security and create new factors of uncertainty.

Each of these properties or functions may indicate that a digital human being has certain advantages over an ordinary human and the specific legal status of a special subject (persona) of the offense. Such features should be directly enshrined in law, for example, in the wording «a person with artificially improved physical or cognitive properties».

Reason, cunning, ability to cooperate and other useful skills once became the basis for Homo sapiens to surpass and destroy all its other competitors (Homo habilis, rudolfensis, ergaster, erectus, floresiensis, antecessor, heidelbergensis, neanderthalensis, rhodesiensis, cepranensis, georgicus etc.). Therefore, there is reason to fear and expect similar behaviour from a digital human being who will be able to continue the escalation of pure intelligence in all spheres of economic,

${ }^{16}$ Dunbar R. I. M. Neocortex size as a constraint on group size in primates. Journal of Human Evolution, Vol. 22. Issue 6. June 1992. P. 469-493. doi: https://doi.org/10.1016/0047-2484(92)90081-J (дата звернення: 21.07.2021).

17 Лем С. Системы оружия двадцать первого века. Библиотека ХХІ века. Москва: АСТ, 2003. 602 с.

18 Farr M. K. Knightmare on Wall Street - Revenge of the Machines. CNBC, 8 Aug 2012. URL: https://www.cnbc.com/id/48575707 (дата звернення: 21.07.2021)/ 
political, corporate, informational and military confrontation both within its species and in relation to Homo sapiens.

Just as artificial intelligence itself does not need to try to become human, so a digital human being does not need to decide what part of their previous existence they must leave and what part of themselves must be replaced by something new inorganic for further improvement.

In the confrontation between man and artificial intelligence, open aggression not expected. Most likely, these will be methods of soft power. Artificial intelligence can first eliminate the need for a human to think, and then eliminate the ability to do it. It is difficult to predict, as will be the case with a digital human being. But digital human being may not notice it, as can Homo sapiens. The ability to think was and still is a victorious evolutionary skill of Homo sapiens, but in the absence of need, any skill is easily lost due to lack of training.

Therefore, certain areas of activity are already beginning to disappear. Yes, autopilots not only can destroy the profession of pilot, driver or operator, but destroy any knowledge about steering.

The emergence, consolidation and spread of the digital human being mark the beginning of a new civilization. It can be hostile, friendly or neutral to the previous one, but it will definitely be different.

Conclusions. The path that humanity has developed over the past 100 years is associated with artificial evolution (gene-culture coevolution or biocultural evolution, technological-physiological evolution, or metabolic evolution) and it is constantly accelerating.

Thus, the modern evolution of human being into digital human being occurs in several main directions, in particular: 1) bioengineering; 2) creation of a living being that combines organics with inorganics, formation of a cybernetic organism (cyborg); 3) creation of an inorganic life form.

The possibility of combining carbon technology (human being) with silicon technology (artificial intelligence, implants, objects of robotics), or transfer the 
structure of the human brain one neuron by one to inorganic or semi-organic carrier, creates a new powerful challenge for legal doctrine.

Implants that improve certain physical properties of the human body (strength, agility, flexibility, endurance, etc.) can eliminate heavy, dangerous or tedious physical labour, as well as expand horizons (better to hear, see, perceive all the signals of the world etc.). Implants that improve certain human cognitive properties (memory, analytical skills, processing significant amounts of information, the ability to distinguish the main from the insignificant, mobility of the mind, the ability to argue and find relationships, come to conclusions through a chain of thought, critical thinking, breadth of thinking etc.) are able to free the mind from routine work or just as significantly improve its results.

Increasing interaction between the neural system of the human brain and neural networks of artificial intelligence is expected. They can learn to complement and train each other in some way.

But the problem is the inability to recognize the algorithm of self-learning actions of artificial intelligence during decision making. It will be difficult to determine whether a certain act of behaviour of a digital human being is his free will, or the decision was made by artificial intelligence algorithms, which are built into a particular implant.

The weakness of the will of the individual may call into question the existence of a factual basis for legal liability. Similarly, cases of unconscious use of a digital human being to commit an offense or an undesirable act in connection with unlawful interference or control of his or her implant under the control of artificial intelligence are not excluded.

Researched properties or functions may indicate that a digital human being has certain advantages over an ordinary human and the specific legal status of a special subject (persona) of the offense. Such features should be directly enshrined in law, for example, in the wording «a person with artificially improved physical or cognitive properties». 
There are reasons to fear and expect the digital human being to escalate pure intelligence in all spheres of economic, political, corporate, informational and military confrontation, both within its own kind of being and in relation to Homo sapiens.

Artificial intelligence can eliminate the need for humans and digital human being to think, and then eliminate the ability to do it altogether. The ability to think was and still is a victorious evolutionary skill of Homo sapiens, but in the absence of need, any skill is easily lost due to lack of training.

The emergence, consolidation and spread of the digital human being mark the beginning of a new civilization. It can be hostile, friendly or neutral to the previous one, but it will definitely be different.

\section{Список використаних джерел}

1. Computer inside the heart aims to aid treatment. BBC News, Technology, 2 March 2020. URL: https://www.bbc.com/news/av/technology51660393/computer-inside-the-heart-aims-to-aid-treatment (дата звернення: 21.07.2021).

2. Dunbar R. I. M. Neocortex size as a constraint on group size in primates. Journal of Human Evolution. 1992. Vol. 22. Issue 6. Pp. 469-493. doi: https://doi.org/10.1016/0047-2484(92)90081-J (дата звернення: 21.07.2021).

3. Farr M. K. Knightmare on Wall Street - Revenge of the Machines. CNBC, 8 Aug 2012. URL: https://www.cnbc.com/id/48575707 (дата звернення: 21.07.2021).

4. Haldane J.B.S. The Origin of Life. 1929. URL: https://www.uv.es/ orilife/textos/Haldane.pdf (дата звернення: 21.07.2021) (Cite: Tirard S. J. B. S. Haldane and the origin of life. J Genet. 2017 Nov; 96(5):735-739. doi: https://doi.org/10.1007/s12041-017-0831-6. PMID: 29237880) (дата звернення: 21.07.2021).

5. Haig Matt. Notes on a nervous planet. Country Edinburgh, United Kingdom: Canongate Books, 2019. 320 pp.

6. Kaku M. Physics of the Impossible: A Scientific Exploration Into the World of Phasers, Force Fields, Teleportation, and Time Travel. Doubleday Publishing, Duke University Libraries. 2008. 456 p.

7. Kopeček Tomáš. Anthropomorphization of Artificial Intelligence. Bachelor thesis. Masaryk University Department of Sociology. Brno 2015. 40 p.

8. Malapi-Nelson Alcibiades. Classical Cybernetics and Transhumanism: A Reply to Richmond's Review of The Nature of the Machine and the Collapse of 
Cybernetics. Sage Publishing, Philosophy of the Social Sciences. 2018. Vol. 49. Issue 1. Pp. 64-68. doi: https://doi.org/10.1177/0048393118811308 (дата звернення: 21.07.2021).

9. Oparin A. I. The Origin of Life (translation by Ann Synge of A. I. Oparin. Proiskhozhdenie zhizny. Moscow. Izd. Moscovskiy Rabochiy). 1924. URL: https://breadtagsagas.com/wp-content/uploads/2015/12/AI-Oparin-TheOrigin-of-Life.pdf (дата звернення: 21.07.2021).

10. Radutniy O. E. Novel Criminal Delicts Related to Digital Human Being. Herald of the Association of Criminal Law of Ukraine. 2020. Vol. 1, No 13. doi: https://doi.org/10.21564/2311-9640.2020.13.204761 (дата звернення: 21.07.2021).

11. The Cambridge Declaration on Consciousness of 7 July 2012. Written by Philip Low and edited by J. Panksepp, D. Reiss, D. Edelman, B. Van Swinderen, P. Low and C. Koch. University of Cambridge. URL: $\mathrm{http}: / /$ fcmconference.org/img/CambridgeDeclarationOnConsciousness.pdf (дата звернення: 21.07.2021).

12. Zhang Y., Ptacin J., Fischer E. et al. A semi-synthetic organism that stores and retrieves increased genetic information. Nature. 2017. Issue 551. Pp. 644-647. doi: https://doi.org/10.1038/nature24659 (дата звернення: 21.07.2021).

13. Ахромеева Т. С., Малинецкий Г. Г., Посашков С. А. Пределы и риски цифровой трансформации. Цифровая трансформация. 2020. № 2 (11). C. 51-57. doi: https://doi.org/10.38086/2522-9613-2020-2-51-57 (дата звернення: 21.07.2021).

14. Лем С. Системы оружия двадцать первого века. Библиотека XXI века. Москва: АСТ, 2003. 602 с.

15. Радутний О.Е. Правові аспекти феномену цифрової людини в кібернетичному та іншому просторі. Забезпечення кібербезпеки: правові та технічні аспекти: збірник тез наукових доповідей науково-практичного семінару (м. Харків, 8 листоп. 2018 р.). Харків: Нац. аерокосм. ун-т ім. М. Є. Жуковського «XАI», 2018. 112 с.

16. Радутний О. Е. Розвиток кримінально-правової доктрини у напрямку визнання штучного інтелекту та цифрової людини суб'єктом правовідносин та суб'єктом злочину. Ефективність кримінального законодавства: доктринальні, законотворчі та правозастосовні проблеми іï забезпечення: матеріали міжнар. наук.-практ. кругл. столу (м. Харків, 17 трав. 2019 р.). Харків: Константа, 2019. 324 с.

17. Радутний О. Е. Кваліфікуючі ознаки, пов'язані з досягненнями наукового прогресу (біоінженерія, штучний інтелект, неорганічна та змішана форма життя). Актуальні проблеми кримінального права, кримінологї та кримінально-виконавчого права: матеріали Всеукр. наук.-практ. конф. (м. Дніпро, 25 трав. 2018 р.). Дніпро: Дніпроп. держ. ун-т внутр. справ, 2018. $214 \mathrm{c}$. 
18. Чурсин Н. Н. Понятие тезауруса в информационной картине мира: монография. Луганск: Изд-во «Ноулидж», 2010. 305 с.

\section{REFERENCES}

1. Computer inside the heart aims to aid treatment. (2020). BBC News, Technology. URL: https://www.bbc.com/news/av/technology51660393/computer-inside-the-heart-aims-to-aid-treatment.

2. Dunbar, R. I. M. (1992). Neocortex size as a constraint on group size in primates. Journal of Human Evolution, vol. 22, issue 6, 469-493. doi: https://doi.org/10.1016/0047-2484(92)90081-J.

3. Farr, M. K. (2012). Knightmare on Wall Street - Revenge of the Machines. $C N B C, 8$. URL: https://www.cnbc.com/id/48575707.

4. Haldane, J. B.S. (1929). The Origin of Life. URL: https://www.uv.es/ orilife/textos/Haldane.pdf (дата звернення: 21.07.2021) (Cite: Tirard S. J. B. S. Haldane and the origin of life. J Genet. 2017 Nov; 96(5):735739. doi: https://doi.org/10.1007/s12041-017-0831-6. PMID: 29237880).

5. Haig, Matt. Notes on a nervous planet. Country Edinburgh, United Kingdom: Canongate Books, 2019. 320 pp.

6. Kaku, M. (2008). Physics of the Impossible: A Scientific Exploration Into the World of Phasers, Force Fields, Teleportation, and Time Travel. Doubleday Publishing, Duke University Libraries. 456 p.

7. Kopeček, Tomáš. (2015). Anthropomorphization of Artificial Intelligence. Bachelor thesis. Masaryk University Department of Sociology. Brno 2015. $40 \mathrm{p}$.

8. Malapi-Nelson Alcibiades. (2018). Classical Cybernetics and Transhumanism: A Reply to Richmond's Review of The Nature of the Machine and the Collapse of Cybernetics. Sage Publishing, Philosophy of the Social Sciences, vol. 49, issue 1, 64-68. doi: https://doi.org/10.1177/0048393118811308.

9. Oparin, A.I. (1924). The Origin of Life (translation by Ann Synge of A. I. Oparin (1924). Proiskhozhdenie zhizny. Moscow: Izd. Moscovskiy Rabochiy). URL: https://breadtagsagas.com/wp-content/uploads/2015/12/AIOparin-The-Origin-of-Life.pdf.

10. Radutniy, O.E. (2020). Novel Criminal Delicts Related to Digital Human Being. Herald of the Association of Criminal Law of Ukraine, vol 1, No 13. URL: http://vakp.nlu.edu.ua/issue/view/12594. doi: https://doi.org/10.21564/23119640.2020.13.204761.

11. The Cambridge Declaration on Consciousness of 7 July 2012. Written by Philip Low and edited by J. Panksepp, D. Reiss, D. Edelman, B. Van Swinderen, P. Low and C. Koch. University of Cambridge. URL: http://fcmconference.org/img/CambridgeDeclarationOnConsciousness.pdf.

12. Zhang, Y., Ptacin, J., Fischer, E. et al. (2017). A semi-synthetic organism that stores and retrieves increased genetic information. Nature, 551, 644647. doi: https://doi.org/10.1038/nature24659. 
13. Akhromeeva, T.S., Malinetskiy, G.G., Posashkov, S.A. 2020). Limits and Risks of Digital Transformation. Cifrovaja transformacija - Digital transformation, 2 (11), 51-57. doi: https://doi.org/10.38086/2522-9613-2020-2-5157 [in Russian].

14. Lem, S. (2003). «Sistemi orugija dvadzat pervogo veka [Weapon systems of the twenty-first century]. Biblioteka XXI veka - Library of the XXI century. Moscow: AST [in Russian].

15. Radutniy, O. (2018). «Pravovi aspekty fenomenu tsyfrovoi liudyny v kibernetychnomu ta inshomu prostori [Legal Aspects of the Phenomenon of Digital Man in Cybernetic and other Space.]». U Zabezpechennia kiberbezpeky: pravovi ta tekhnichni aspekty: Nauk.-prakt. Seminar [Cybersecurity: Legal and Technical Aspects], 57-63. Kharkiv: Nats. aerokosm. un-t im. M. Ye. Zhukovskoho «KhAI» [in Ukrainian].

16. Radutniy, O. (2019). «Rozvitok kriminalno-pravovoi doktrini u napryamku viznannya shtuchnogo intelektu ta zifrovoi ludini subyektom pravovidnosin ta subiektom zlochinu [Growth of the criminal legal doctrine in the direction of recognition of artificial intelligence and digital rights as a subject of legal relations and the subject of crime]». In Efektivnist kriminalno-pravovogo zakonodavstva: doktrinalni, zakonotvorchi ta pravozastosovni problem ii zabezpechennya: Mizhnar. nauk.-prakt. konf. [Effectiveness of Criminal Legislation: Doctrinal, Legislative and Law Enforcement Problems of its Provision], 202-13. Kharkiv: Konstanta [in Ukrainian].

17. Radutniy, O. (2018). «Kvalifikuiuchi oznaky, pov'iazani z dosiahnenniamy naukovoho prohresu (bioinzheneriia, shtuchnyi intelekt, neorhanichna ta zmishana forma zhyttia) [Qualifying Traits Related to Scientific Advances (bioengineering, artificial intelligence, inorganic and mixed forms of life)]». U Aktualni problemy kryminalnoho prava, kryminolohii ta kryminalnovykonavchoho prava: Vseukr. nauk.-prakt. konf. [Topical Issues of Criminal Law, Criminology and Criminal Law], 41-3. Dnipro: Dniprop. derzh. un-t vnutr. sprav [in Ukrainian].

18. Chursin, N.N. (2010). Ponyatie tezaurusa v informazionnoi kartine mira [The concept of thesaurus in the information picture of the world]. Lugansk: Izd-vo Noylidge [in Russian].

\section{Радутный А. Э. Правовой взгляд на цифрового человека}

В продолжение предыцущих исследований в статье предлагается правовой взгляд на отдельные признаки иифровой человека и формулировки de lege ferenda признаков специального субъекта правонарушения. B качестве одной из проблем рассматривается вопрос искривленности воли циифрового человека, решения за которого были приняты искусственным интеллектом, что может поставить под сомнение наличие фактического основания юридической ответственности. Относительно цифррового человека аргументирована возможность эскалации улучшенного интеллекта 
во всех областях экономического, политического, корпоративного, информационного и военного противостояния. Доказано, что искусственный интеллект может устранить для человека и цүифрового человека необходимость думать, а затем вообще устранить способность к такой деятельности.

Ключевые слова: искусственный интеллект, субъект правонарушения, биоинженерия, киборг, неорганическая форма жизни, цүифровой человек, Homo numeralis, Homo digitalis, Homo horologium, Homo sapiens.

\section{Радутний О. Е. Правовий погляд на цифрову людину}

У продовження попередніх досліджень в статті пропонується правовий погляд на окремі ознаки циифрової людини та формулювання de lege ferenda ознак спеціального суб’єкта правопорушення. В якості однієї 3 проблем розглядається питання схибленості волі иифрової людини, рішення за яку приймається штучним інтелектом, щуо може поставити під сумнів наявність фактичної підстави юридичної відповідальності в діях людини.

Сформульовано тезу відносно розвитку еволючиї сучасної людини в uзифрову людину (генокультурна коеволючія, біокультурна, технологічнофізіологічна, або метаболічна еволючія) в кількох основних напрямках: 1) біоінженерія; 2) створення живої істоти, щзо поєднує органіку 3 неорганікою, формування кібернетичного організму (кіборга); 3) створення неорганічної форми життя. Доведено, щуо можливість поєднання вуглецевої технології (людина) з кремнієвою технологією (штучний інтелект, імпланти, об'єкти робототехніки) або перенесення структури людського мозку по одному нейрону на неорганічний або напіворганічний носій створює новий потужний виклик для правової доктрини, який необхідно своєчасно вирімувати.

Обгрунтовано тезу про очікування посилення взаємодії між нейронною системою мозку людини та нейронними мережами итучного інтелекту, які можуть навчитися якось доповнювати і тренувати один одного. Проблема полягає у неможливості розпізнати алгоритм самонавчальних дій штучного інтелекту під час прийняття рішень, а так самовизначити, чи обумовлений певний акт поведінки цицфрової людини ї̈ вільною волею, або рішення було прийнято за неї алгоритмами итучного інтелекту, які вбудовані в той чи інший імплант.

Відносно циифрової людини аргументовано можливість ескалації покращуеного інтелекту у всіх сферах економічного, політичного, корпоративного, інформаційного та військового протистояння. Доведено, щзо итучний інтелект може усунути для людини та циифрової людини необхідність думати, а потім взагалі виключити здатність до изього.

Здійснено висновок, щзо циифрова людина має певні переваги перед звичайною людиною та специфічний правовий статус спеціального суб'єкта (особи) правопорушення. Такі ознаки мають бути прямо законодавчо 
закріплені, наприклад, у формулюванні «особа зі штучно покращеними фізичними чи пізнавальними властивостями».

Автор стверджує, що поява, консолідація та поширення цифрової людини знаменує собою початок нової цивілізації, яка може бути ворожою, дружньою або нейтральною до попередньої, але без сумніву іншою.

Ключові слова: штучний інтелект, суб'єкт правопорушення, біоінженерія, кіборг, неорганічна форма життя, иифрова людина, Ното numeralis, Homo digitalis, Homo horologium, Homo sapiens. 